\title{
Технологии формирования ответственного поведения старшеклассников: дидактический аспект
}

На современном этапе развития дидактической науки ответственность как важнейшая личностная характеристика современного старшеклассника, чрезвычайно редко становится объектом, как теоретического анализа, такиэмпирического исследования. В современной отечественной педагогике существует определенный дефицит технологий направленного воздействия на развитие самореализации школьников, установок на его профессиональный и социальный успех. Одной из технологий развития ответственности является распространение процессов осмысления за пределы наличной актуально воспринимаемой ситуации, непосредственного перцептивного поля, в план представления, воображения, идеаторных содержаний сознания, что может рассматриваться как задача смысл, инициирующая формирование личностной сферы старшеклассника.

Ключевые слова: ответственность, ченностно-смысловая срера личн бс и, самореализация, технологии инициации смыслообразования, задачи нағмысл

Сегодняшний день требует от выпускника не столько умений вь Пол яп указания, сколько решать проблемы жизни самостоятельно, провопить и-ледования, давать экспертные заключения, создавать проекты. Изменив山еео качество жизни диктует дать школьникам такое образование, котороелидгөнвит их к жизни в информационно-динамичном обществе, меняющемся мире, причем это касается и личной и профессиональной сфер.

Ответственность является интегральным своу м личности, проявляющееся в осознанном, инициативном, самостоле, зом, социально позитивном поведении. Развитость различных компонен (-) ответственности определяет во многом успешность деятельности суб 27 , гарантированность достижения результатов деятельности своими сил ми, с учетом возможных неожиданностей и трудностей. Ответственность явл ел ятиногопараметральным качеством, которое следует изучать с позиции си екго подхода. Содержание ответственности раскрывается исходя из ее стуу - /ры, включающей: мотивационные, ценностносмысловые, эмоциональне, когнитивные, динамические, регуляторные и результативные компоненты (1изнаки проявления ответственности разнообразны и многочисленны, в кал ес ве ее коррелятов выступают характеристики личности, которые так же связ ван с ее развитием как субъекта и субъекта деятельности: самостоятельн 890 , надежностью, стрессоустойчивостью, личностной зрелостью, ориенациеи на смысл. Проблема влияния ответственности на различные сферы жизн-ятельности личности по-разному освещается в отечественной и зар) юе ной пихолого-педагогической науке: с позиции нравственной и морапьн эической (В.В. Знаков, Х. Хекхаузен, М.М. Бахтин, Ж.П. Сартр, В. Франкл); оо бшения внутреннего и внешнего в ответственности личности (А.Г. Спиркин, 
К.А. Абульханова-Славская, К.Г. Юнг, А.С. Прангишвилли); рассматривается ответственность как действие (Р. Ассаджоли, Э.И. Рудковский, Б.Ф. Ломов); соотношение свободы и ответственности (Д.А. Леонтьев, К. Роджерс, А.В. Брушлинский, В. Франкл.); соотношение социальной и личной ответственности (В.Г. Сахарова, А. Адлер, В.А. Розанова); ответственность с позиции казуальной атрибуции и теории локуса контроля (К. Муздыбаев, В.П. Трусов, Ф. Хайдер, Дж. Роттер, Дж. Келли); системный подход к изучению ответственности (А.И. Крупнов, Б.Ф. Ломов, В.П.Прядеин), проблема культурной ответственности (В.Ф. Василюк), ответственность в структуре смысловой регуляции (Д.А. Леонтьев, Е.Р. Калитвиевская), исследования профессиональной ответственности (В.А. Бодров, В.Я. Орлов, А.А. Деркач), проблема возрастных особенностей ответственности (Т.Ф. Иванова).

Однако, на современном этапе развития дидактической науки ответственность как важнейшая личностная характеристика современного старшеклассникӓ чрезвычайно редко становится объектом, как теоретического анализа, так игмпирического исследования. В современной отечественной педагогике сущес вуе определенный дефицит технологий направленного воздействия на аз итие самореализации школьников, установок на его профессиональный икоциал ғый успех, в то время как недостаточный уровень развития субъектнь к- сів личности выпускников школ, в том числе ответственности, рефлекси ууе я-оществом повсеместно. Наиболее разработанной являются исследования: прблемы формирования ответственности у дошкольников и младших шкояийов (Данькова Е.Н., Иванова Т.Ф.), формирования ответственности как атриб) лпомичиеской культуры школьника (Тюлькова И.А.), формирования добросовестного выполнения учебных действий (М.В. Матюхина, С.Г. Ярикова), формиров А волевых качеств учащихся (Лайзане Л.В.). При этом фактически нет работ, ори ' рованных на исследование тех технологий, которые станут реальным инсть ментарием учителя по развитию личностных особенностей старшеклассник- $\mathcal{H}$-уровне их ценностно-смыслового принятие. Возникающее противоречие 1 пу возросшей потребностью общества в формировании ответственной лич 00 ии неразработанностью теоретического аспекта и направленной работы (a) 0овн реального образовательного процесса определило проблему исслед ал и, результаты которого изложены в настоящей статье.

Для практического ы-рлнения поставленных целей и задач исследования были использованыне клько групп методов анализа и диагностики. В первую группу вошли метष Ы, ртносящиеся непосредственно к процессу исследования: сравнительный атлиидей и концепций, анкетирование, самоотчет, взаимооценка учащихся Муителей. Во вторую группу методов вошли стандартизированные психометричекие диагностики: «Ценностные регуляторы организационного поведени "Т.С. Кабаченко); «Тест смысложизненых ориентаций» (Д.А. Леонтьев); тес «эмоактализация личности» (Н.Ф.Калина); «Определение направленности личн (сти» (ориентационная анкета) (Б. Басса); «Диагностика ответственности» (авᄀ Дккая методика В.П. Прядена). В качества третьей группы методов исследования 
необходимо выделить обучающий эксперимент, в ходе которого происходила апробация тех технологий, которые имеют дидактический потенциал развития ответственности у старшеклассников, и которые были разработаны учителями и школьными психологами, участниками данной программы.

В диагностической и экспериментальной части исследования принимали участие старшеклассники гг. Ростова-на-Дону и Шахт (Ростовской области) в количестве 248 чел. в возрасте 16-18 лет. В двух классах проводилась апробация экспериментальной программы, в которых апробировались технологии, обладающие определенным дидактическим потенциалом развития ответственности у старшеклассников, а остальные школьники - учились в контрольных классах. Экспериментальное исследование проводилось в течение 2008-2009 учебного года. На начальном и заключительном этапе диагностировались параметры, которые свидетельствовали об уровне ответственности и особенностях развития ценностно-смысловой сферы старшеклассников.

В результате проведенного исследования были сформулированы следующ выводы.

1. Педагогическая технология развития ответственности будет эффектив реализовываться в образовательном процессе современно 200 щебразовательного учреждения, если механизмом становлен я о вественности старшеклассников выступит рефлексивная деятепьнос аа каждом из следующих этапов: формирование представлений боветственности и мотивации выполняемой деятельности, становл ғне мактических навыков проявления ответственного поведения в различяых видах деятельности, осознанное самостоятельное использ ве ие накопленного опыта ответственного поведения.

2. Педагогическая технология развития отве ственности старшеклассника будет способствовать формированию Верелятов, в качестве которых выступают характеристики личнос 1 рторые так же связываются с развитием субъектной позиции: саN Ос рянельностью, надежностью, стрессоустойчивостью, личностной з ее ю-ю, ориентацией на смыслораскрытие и смыслостроительство, ви со пй поисковой активностью, развитым самоконтролем, компетентион.

3. Деформации личнс о-смысловой сферы старшеклассников ведут к закреплению нет Тувных ценностно-смысловых установок, способов восприятия де Стительности, появлению смысловых смещений, клише, которые огрлел, юот все аспекты поведения, в том числе - особенности учебной дөлтельности.

4. Спецा ам организованная методическая система с использованием направлы ых технологий инициации смыслообразования (с использованием 60. текста аналогичного реальным жизненным ситуациям характерным для 7нной возрастной группы учащихся, технологии перехода от реального субъективного опыта - к субъектному, жизненному миру, через раскрытие 
личностных смыслов данного контекста, трансформация смыслов в совместной деятельности, смыслопорождающий диалог) позволит учителю моделировать учебные ситуации, ориентированные на повышение ответственности старшеклассников.

Данные теоретического анализа, диагностики и экспериментальной апробации позволили выявить технологию инициации смыслообразования, которая ориентирована на формирование ответственных форм поведения.

Смысловая сфера личности является открытой системой по отношению к миру и другим смысловым мирам, как отдельных личностей, так и произведений культуры. Это означает, что человек не ограничен непосредственным индивидуальным опытом в качестве источника смыслов, а обладает безграничными возможностями расширения смыслового мира за счет других смысловых миров. Вступая в такое взаимодействие, человек раздвигает границы собственного смыслового мира увеличивая возможности и расширяя тем самым ресурсы саморегуляции (1)

Леонтьев Д.А. в процессах саморегуляции обнаруживает два противополо, ны рода процессов, находящихся друг с другом в непосредственной взаимосвя и, виде чередования сменяющих друг друга фаз взаимодействия с миром. Порвая ља предполагает раскрытие потенциала свободы. Она включает в себ р спектра возможностей действия, максимизацию потенциальных смы льs, которые может нести в себе ситуация, толерантность к неопределенностылорая фаза закрытие, сужение спектра возможностей, совладание с ик иso осуществление выбора и переход к реализации, преодс лни меоределенности, раскрытие потенциала ответственности. «Разрыв этих двухфаз и абсолютизация одной из них приводит к неполноценному, одноб ке му взгляду на человеческое существование: абсолютное познание и пониман и Сорванное от выбора и реализации, так же не полноценно, как абсолютнля ц.ленаправленность и реализация, оторванная от понимания и осмысления вб. Мужностей» [4, с. 497].

Таким образом, раскрытие потенциа . смысла от внутреннего плана, кего в Аец ней реализации в процессе собственного бытия. Н.С. Пряжников подчерки аи но проблема соотношения свободы и ответственности личности становит А иолее актуальной для исторических периодов, характеризующихся трансыо мациями идеологических, моральных и ценностных устоев общества. Автор реально возникшая пие д), начительными массами людей проблема свободы выбора. В психологи ?ск м смысле эта проблема не менее сложная, чем проблемы связанные с огра иче ием свободы» [5]. Проблема построения собственной идентичности в ИТ, циях личностного самоопределения всегда связана с выбором модели, rеме идеализированного ориентира, помогающего в выстраивании индивиду сного вектора саморазвития. Н.С. Пряжников считает, что важную роль пру Эум играют идеалы, образы людей которым хочется подражать и антигерои, от кобрых необходимо дистанцироваться в своем развитии и карьере. Проблема c ح,оит в том, что нередко образ идеала входит в противоречие с реальными 
возможностями человека. Возможности приблизиться к своему «образу достижений ограничиваются рядом факторов, например, социально-экономическими. Л.А. Журавлев и А.Б. Купрейченко, анализируя обозначенную проблему, задаются вопросом о правомерности вмешательства со стороны в процесс выбора своего идеала. Возможно ли ориентировать, например, детей или подростков на средний уровень успешности, подменяя при этом подлинное самоопределение внешней детерминацией? Авторы подчеркивают, что наиболее правильно дать самоопределяющемуся субъекту понимание ответственности как неотъемлемого качества свободной личности [2].

Именно осознание ответственности позволяет человеку раскрыть для себя смысл ситуации, и определить свое место и роль в ней, стать подлинным субъектом самоопределения и выбрать для себя наиболее подходящий сценарий развития. Ответственность, как характеристика субъекта, позволяет человеку определять наиболее адекватные его возможностям, способностям и подлинным потребностям цели и задачи в жизни, а так же формировать свои ожидания, притязания, ценнсти, идеалы. В качестве основных проявлений продуктивности Э. Фром наз,В ет заботу и ответственность. «Ответственность - это не обязанность, напожен - $A$ на меня извне, она мой ответ на чью-то надобность, небезразличн юо не $[6$, с. 86]. Понимание Э. Фромом плодотворной любви близко по смь Слу ка̃негории социальной ответственности. «Любить человека плодотворно-значи-аботиться о нем и чувствовать ответственность за его жизнь, не толькб ар физическое существование, но и за развитие всех его человеческих сил лподерорная любовь несовместима с пассивностью, со сторонним наблюдением зажизнью любимого человека; она означает труд, заботу и ответственнос (9 его развитие» [6, с. 87].

Принятие ответственности помогает субъекту п ав ьно оценить, осмыслить причины жизненных успехов и неудач, защития (бя от завышенных ожиданий, нереалистических притязаний, больших жизне ю्х разочарований и потерь.

В таком понимании проблема осознани 71 етственности является «задачей на смысл». «В наиболее общем виде задач Ан смысл есть задача определения места объекта или явления в жизнедеятель но мубъекта» [3, с. 258-259]. Соответственно, с осознанием ответственности, по ын-тся субъективная значимость «выбранных» объектов или явлений в струуту, смысловой реальности.

Задача на смысл може тазиться в отношении собственного действия (ради чего я это сделал, делаю, делать; какие мотивы за этим стоят; какие потребности или ценности нго хо рт реализацию в этом действии, и к каким последствиям оно приведет). Такая же з лача может ставиться в отношении к объектам, явлениям и событиям дей элительности (какое место они занимают в моей жизни, как могут повлиять ная яе икакие иметь последствия) [3]. Осознание ответственности предполагает спо- оность человека ответить себе на данные вопросы.

Ре 10 мем задачи на смысл является более полное, по сравнению с исходной ситуашй, осознание смысловых связей определенного объекта, явления или

ей чия с жизнедеятельностью субъекта в целом. 
Одной из линий развития смысловой сферы личности является распространение процессов осмысления за пределы наличной актуально воспринимаемой ситуации, непосредственного перцептивного поля, в план представления, воображения, идеаторных содержаний сознания [4].

Возможность полагания ответственности за что-либо, или кого-либо проигрывается в режиме ее предвосхищения, в плане представления. Человек мысленно занимает определенную позицию в предлагаемых обстоятельствах, проигрывает в идеальном плане различные варианты развития событий, переживает смысл данной ситуации, предпринимаемых действий и их возможных последствий для себя и окружающих.

План воображения отделен от плана практической деятельности, воображаемые мотивы не переноситься непосредственно в практическую деятельность, но в силу целостности смысловой сферы личности, смысловые образования, проявляющиес в плане воображения, не изолированы от смысловых образований регулируюших практическую деятельность. Воображение задает «зону ближайшего развития, личности в целом [4, с. 285], идеаторное предвосхищение возможных пос ед твии за принимаемое решение повышает возможности личности более глубокого разностороннего осмысления ситуации при принятии на себя ответст е上нсли.

Другой ракурс определения ответственности предполагае рас-м⿰亻енене ее не только через призму инстанции и санкции, но и через соотнеме ие с проблемой свободы и необходимости. Понятие свободы в его психлгическом аспекте является важнейшей характеристикой гуманистическ п пөхода, в отличии от теоретических ориентаций, отражающих тенденции пандеерминизма, в которых проблема свободы рассматривается сквозь призу у ограничений - вины и наказания. В данном случае речь не идет о проявлен ия ичностной свободы, так как нет понимания подлинной личностной ответсге ности, которая подменяется внешними формами ее проявлении в виде санки Или страха перед ними. Э. Фромму принадлежит термин «психологическа б:ственость» которая не имеет ничего общего с наказанием или виной. Ст ах аказания делает человека не способным воспользоваться своим правом олора, или признать свое авторство [6].

В современной педагогиче ком рактике, однако, рассмотренные выше механизмы актуализации личндс \І І ценностей в учебном процессе присутствуют не всегда [1]. Существует д й таких технологий, который будет преодолен, если каждый педагог, работан щи си со старшеклассниками, будет помнить: выраженность ответственности в Стр тегии самореализации старшеклассников предполагает вектор развитин, клльуающий в себя направленность не только на внешний успех, но и удовле вяренность процессом обучения, осознание степени общественной значимо (и оччения, позитивное социальное проявление, установки на созидание. Фо, ирование ответственности старшеклассников связано с развитием соц 10. ентрических компонентов ответственности, чему способствует развитие ценн (стно-смысловой сферы личности, обогащение ее гуманистическими ценA лями и именно этому педагог должен уделять особое внимание. 


\section{Литература}

1. Абакумова И.В. Обучение и смысл: смыслообразование в учебном процессе. (Психолого-дидактический подход). - Ростов н/Д: Изд-во РГУ, 2003.

2. Журавлев А.Л., Поздняков В.П. Социально-психологические трудности становления малого бизнеса в России (анализ общегруппового мнения предпринимателей) // Психологический журнал. - 1993. - № 6. - С. 23-34.

3. Леонтьев Д.А. Психология смысла. - М., 1999. - 364 с.

4. Леонтьев Д.А. Психология свободы: кпостановке проблемы самодетерминации личности // Психологический журнал. - 2000. - № 1. - Т. 21.

5. Пряжников Н.С. Образ «маленького человека» в профессиональном и личностном самоопределении // Психология образования: Проблемы и перспективы. Материалы первой научно-практической конференции. - М.: Смысл, 2004.

6. Фром Э. Человек для себя. Иметь или быть? - Минск: Издатель В.П. Ильин, 1997. 